\title{
Workers' Settlements in the Former Industrial City of Nikšić, Montenegro
}

\author{
Vladimir Bojković1,2* \\ ${ }^{1}$ Department of Civil, Building and Architecture Engineering, Marche Polytechnic University, 60131 Ancona, 12 Via Brecce \\ Bianche, Italy \\ 2 Faculty of Architecture, University of Montenegro, George Washington Boulevard, 81000 Podgorica, Montenegro \\ * Corresponding author, e-mail: bojkovic.v@ucg.ac.me
}

Received: 12 November 2019, Accepted: 12 October 2020, Published online: 13 November 2020

\begin{abstract}
By the end of the Second World War, Montenegro became one of the six republics (Serbia, Croatia Bosnia and Herzegovina, Slovenia, Macedonia) that would later form the Socialist Federal Republic of Yugoslavia. Among the least developed republics, in the context of urbanisation, economy and industry, was Montenegro. Due to the different economic development of the republics, one of the basic goals of socialist management was the equal economic and social growth of all areas. Due to its geographical location and natural resources, Nikšić became the most important industrial centres of Montenegro that developed very rapidly in the post-war period. Among the industrial companies, the ironworks company "Boris Kidrič" had the greatest influence on the urban life of Nikšić. Due to the large numbers of workers required (at one period, the factory had 7500 workers), the ironworks financed the construction of a substantial number of settlements to provide accommodation for workers and their families. Humci and Budo Tomović are the typical workers' settlements built on the urban plans from the 60s. The task of this paper is to present for the first time a different typology of housing in the most significant industrial city of Montenegro, which was created by rapid urbanisation after the Second World War. In the context of architecture and urbanism, the golden age of industrial development of the Nikšić city gave a variety of typologies, especially in terms of housing. A more detailed study of this heritage is yet to begin.
\end{abstract}

Keywords

Nikšić, Montenegro, workers' settlements

\section{Introduction}

In the first half of the 20th century, Montenegro, both as an independent state and then within the Kingdom of Yugoslavia, remains an underdeveloped area. The Balkan Wars and then the First World War influenced the fragile economy of agriculture and crafts. Even in the period between the two world wars, which was a period of recovery for the country, Montenegro remained underdeveloped and insufficiently urbanised due to poverty and population loss from wars (Ivanović, 1979).

After the end of the Second World War, Montenegro became one of the republics of Yugoslavia; it is a change in the political and social order that played a decisive role in the development of both the republics and their cities. In this context, Nikšić is a striking example of a city rapidly developing in economic, cultural and social terms. Physical manifestations of rapid development are particularly striking in the field of architecture and urbanism. One of the primary goals of socialist governance was the equal and equitable development of all republics (Kulić and Mrduljaš, 2012). Since Montenegro was among the most undeveloped, special attention was given to its economic development; Nikšić was chosen as the bearer of industrial development.

There are many reasons why the base of economic and industrial development of Montenegro was formed in Nikšić, but primarily, its geographical position and natural resources.

Nikšić's post-war development required the rapid implementation of urban planning. There was no institution for dealing with the implementation of urban plans and controlled construction of the city after World War II. The organisation of the urban planning service was implemented gradually.

The Council for Urbanism, Communal and Housing Affairs was formed first, then over time, it became the Council of Urbanism in 1955. The Municipal Institute for 
Urban Planning and Design was established in December 1963 and pursued a unique and thoughtful policy of urban and architectural design of the city, ranging from studies and analyses to detailed projects. Hence, design organisations or individuals from outside Montenegro carried out all the post-war urban plans of Nikšić.

The Urban Planning Institute of the Faculty of Architecture, Construction and Geodesy in Zagreb carried out the second post-war urban plan for Nikšić in 1954-58. The author of this plan was the professor and architect, Josip Seissel (1904-1987), assisted by the architects Dragan Boltar (1913-1988), Boris Magaš (1930-2013) and Bruno Milić (Fig. 1).

It is important to note that this urban plan, for the first time, clearly defined and determined the wider and narrower construction zones of the city. This urban plan gave the logical upgrade and development of the first regulatory plan from 1883, produced by architect Josip Šilović Slade (1828-1911) (Fig. 2).

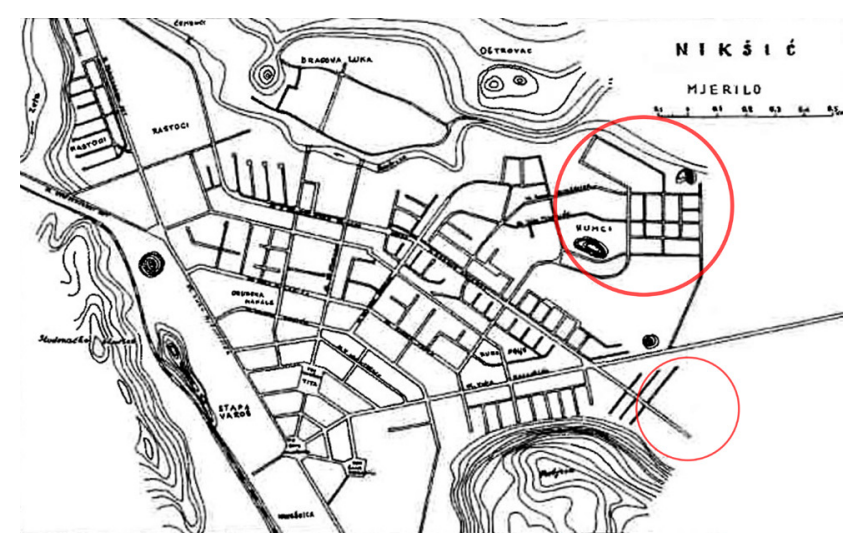

Fig. 1 General urban plan of Nikšić city from 1958. The larger circle marks location of Humci settlement, the smaller marks location of the "Budo Tomović" settlement (Bojković, 2019)

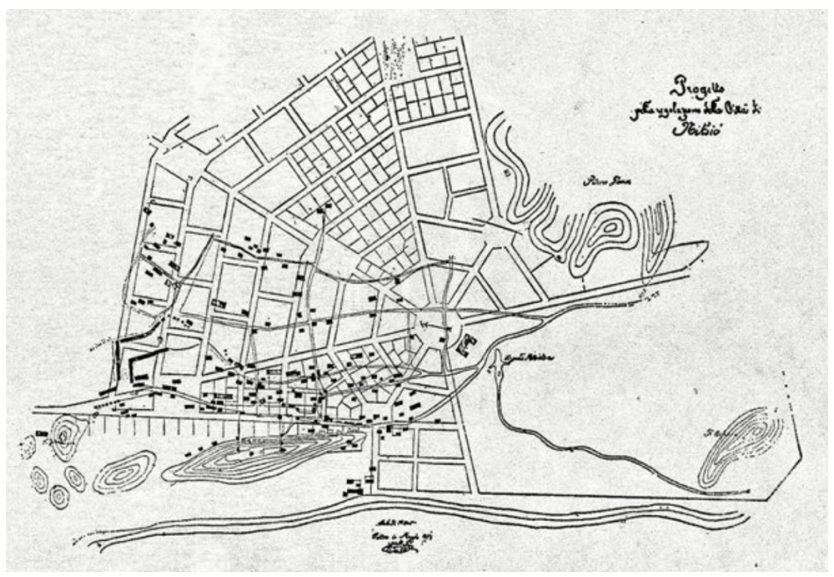

Fig. 2 The first Regulatory Plan of Nikšić, architect Dr. Josip Šilović Slade (Bojković, 2019)
This plan had some similarities with Slade's plan regarding the central green belt, in which the construction of social, public and large-scale facilities was foreseen. Seissel's plan also foresaw that the central part of the city should remain as it was built, according to Slade's plan (Bojković and Bajić, 2015:p.44).

The quality of this urban plan is reflected in that it fully accepted the solutions and basic principles of Slade's urban plan as the basis from which the modern city has evolved. Consequently, there has been a continuity in the development of the city. In addition, the quality of this plan is reflected in the appropriate positioning of buildings of social significance in the continuous zone along the historical core (Bojković, 2018).

Nikšić, as the industrial centre of Montenegro, had much faster development than other cities. According to the data from 1975, the percentage of employment in the social sector in Nikšić was $21.1 \%$, and in Montenegro, it was $17.8 \%$ (Mićković, 2014).

The ironworks company was substantially responsible for such a significant development of the city in the economic as well as in the urban context.

\section{The ironworks company "Boris Kidrič" and its impact on urban development}

The ironworks company "Boris Kidrič", was founded in 1950, and the construction of facilities was completed in 1961. Engineer Rihard Merker supervised the construction of the building (Bulajić, 1972) (Fig. 3).

From its opening until the early 1990s, this industrial giant was one of the most important industrial facilities not only in Montenegro but also in Yugoslavia. After significant political and social changes in Yugoslavia and Montenegro that occurred in the early 1990s, ironworks experienced significant transformations. During

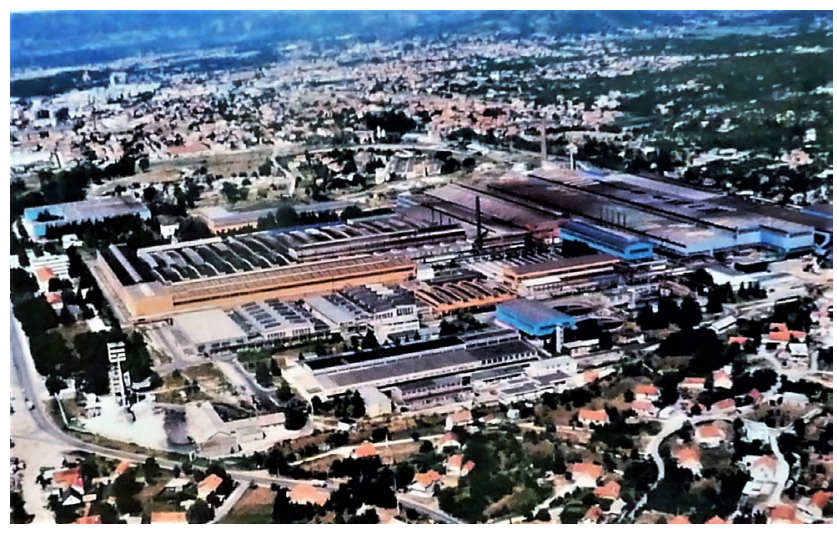

Fig. 3 Aerial view of the ironworks company (Bjelica, 2009) 
the Yugoslav Wars of the 1990s and early 2000s, several rounds of international sanctions were enforced against the Federal Republic of Yugoslavia, which at the time consisted of republics of Serbia and Montenegro after four other republics left the federation. In the first round of sanctions, which were enforced in response to the Bosnian War, and lasted between April 1992 and October 1995, Yugoslavia was placed under a United Nations (UN) embargo. During and after the Kosovo War of 1998-1999, the UN, European Union (EU) and the United States again sanctioned Yugoslavia (Agence France Presse, 2000).

During the period of international sanctions, production and sales of steel dropped rapidly in the Nikšić ironworks company. Privatisation was the only solution for the survival of the factory; however, none of the several privatisations was successful. All this led to the former giant, which employed some 7.5 thousand employees at the time, reducing the number of employees to 1300 after the first privatisation. Today's factory has only a few hundred employees. The lack of a stable future for the ironworks is similarly reflected in the inhabitants of Nikšić and their perspectives.

It is important to note that with the opening of the ironworks company, the basic guidelines for the overall socio-economic development of Nikšić were formed: the development of a communal economy, trade and catering, health, cultural, educational and other institutions and activities. The impact of the ironworks on the city is reflected in the construction of the Humci and Budo Tomović workers' settlements, which significantly influenced the shape of the peripheral city parts.

\subsection{The workers' settlement Humci}

Architect Vsevolod Butovski designed this settlement in the early 1960 s of the 20 th century according to the urban plan (Fig. 4).

The plan provided settlement settings for several thousand workers and their families near the ironworks. The goal of the project was to provide factory workers with temporary accommodation. In the beginning, families would live in Humci until they got bigger apartments in the city, and other families would come in their place. However, this practice was soon abolished, so workers families became permanent owners of apartments. Accommodation facilities consist of two types of buildings in terms of floors, low rise and one-floor facilities.

The low rise buildings are positioned in the western part of the settlement. These objects are set in two parallel rows. Buildings with two-bedroom apartments create a lower order compared to buildings with one-bedroom apartments. With the shorter side, buildings are facing north (Fig. 5).

This part of the city is in the immediate vicinity of the foothills of the surrounding mountains with the strong north winds. The shafts of the lower row of buildings are arranged so that the shorter side comes to the axis of the streets of the upper row; in this way, the impact of wind is not so strong. The buildings are without special architecture, built of brick with a two-sided roof (Fig. 6).

The low-rise buildings contain 10 one-bedroom apartments, six with an east-facing entrance and four with a west-facing entrance. A typical building is a multiplication of a one-bedroom apartment module. A typical one-bedroom apartment is approximately 40 square meters and consists of an entrance with a porch from which it is

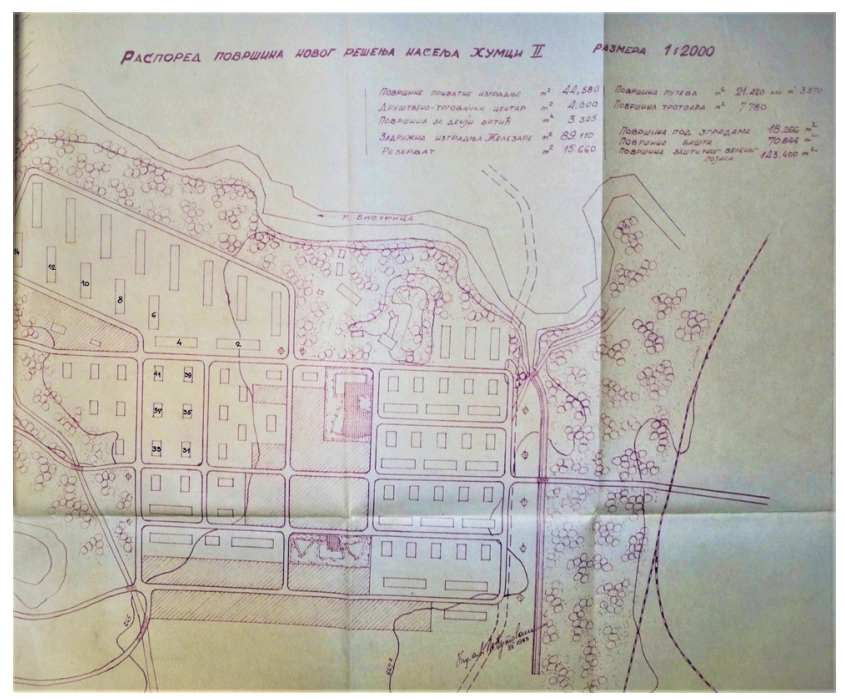

Fig. 4 Urban plan for the workers' settlement Humci, Vsevolod Butovski, 1963 (Bojković, 2019)

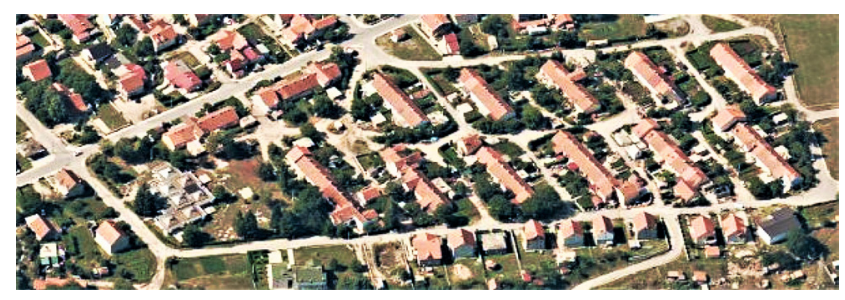

Fig. 5 Aerial view on the Northeast side of Humci with low-rise buildings (Ministry of Sustainable Development and Tourism, Montenegro, 2020)

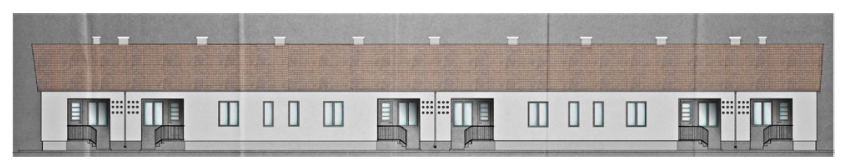

Fig. 6 The facades of a typical workers building (Bojković, 2019) 
possible to enter the toilet or the day zone, which serves as a living room, dining room and kitchen. This space is about 16 square meters, which is not enough for the normal life of an average four-member family. From the living area, one can enter the bedroom or a large storage. Over time, occupants converted the storage space into children's rooms (Fig. 7)

This part of Humci has experienced significant changes primarily by upgrading inhabitants' apartments. The increase in the number of family members, as well as the dysfunctional aspects of apartments, has influenced a larger number of users to develop and reshape their living space. This has led to large unplanned construction and devastation of space because there were no coordinated interventions in the expansion of apartments. Also, there were no legal regulations that prevented inhabitants from expanding their apartments (Fig. 8).

The most common interventions performed by inhabitants on their apartments were the expansion of the living area. Since the apartments are about $4.5 \mathrm{~m}$ wide, expansion was possible only in length. Because of the extension, the former room, which was a living room with a dining room and a kitchen, converted into a bigger living room, while the kitchen, dining room and bathroom located in a new part of the apartment. The result of such interventions in the apartments was that the new living room did not have its own window and natural lighting. Daylight

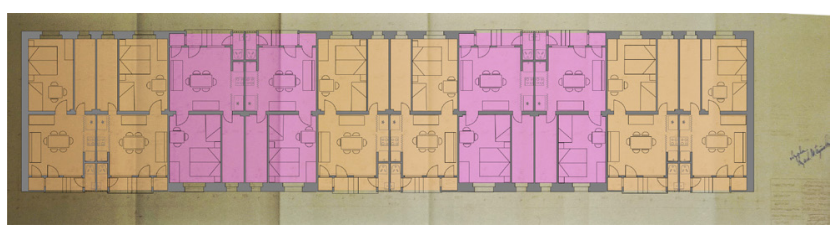

Fig. 7 Typical organisation of the apartments (Bojković, 2019)

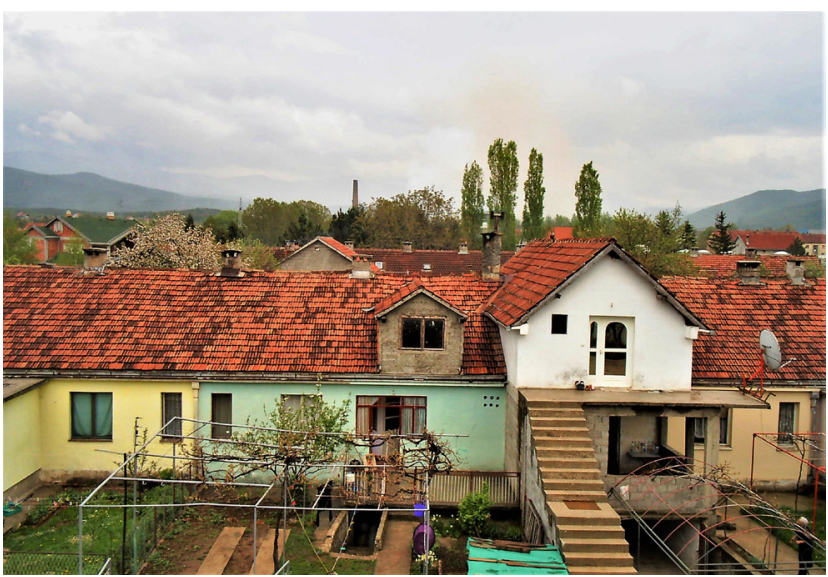

Fig. 8 A view on a typical building with spatial extensions today (Bojković, 2006) came indirectly through the kitchen and dining room. Although these interventions were justified, they did not bring the spatial quality of apartments. Another type of extension was the construction of a bedroom in the attic above the apartment. This room was usually a children's room accessed by a wooden staircase from a smaller room on the ground floor. However, the positive aspects of life are related to social interaction, the formation of a social milieu. The unusual positions of the apartments caused the bedrooms to have windows facing the neighbour's yard, which affected privacy. However, the spatial concept of the buildings connected neighbours. Gradually, social relationships have developed among residents who know and help each other. Even today, visiting among neighbours and drinking coffee is a common habit in Humci. Another positive feature is that the settlement has large green areas provided in the shape of landscaped gardens in front of each apartment. Almost every apartment unit has a vineyard and a green bushy hedge (Fig. 9).

One-storey buildings are located in the eastern part of the settlement. Buildings are made of bricks, and they have a two-sided roof with a simple and modest architecture, which stands out only in the presence of loggia and glazed stairways (Fig. 10).

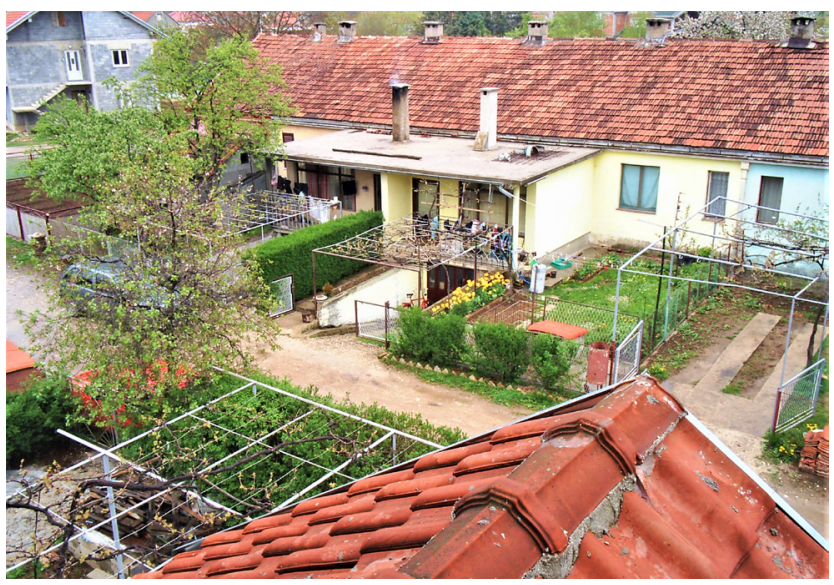

Fig. 9 A view on typical apartment yard (Bojković, 2006)

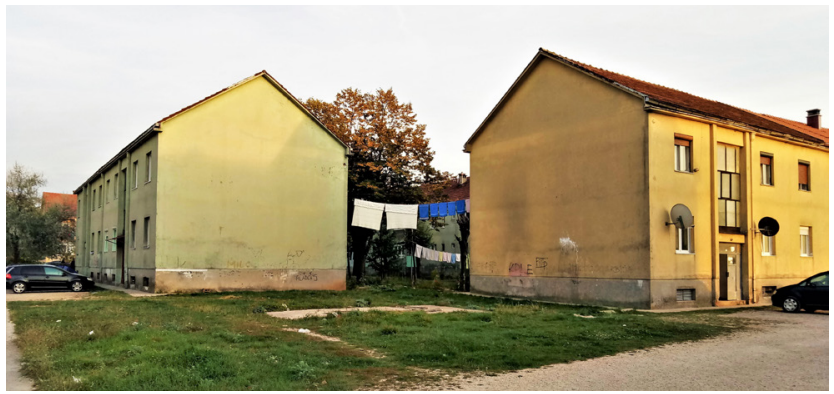

Fig. 10 A view on typical One-storey buildings (Bojković, 2020) 
The two-storey buildings gave a new quality to the inhabitants of the workers' settlement Humci. The structure of the apartments is diverse and consists of one, twoor three-bedroom apartments. The apartments are spacious and comfortable and are allocated depending on the number of family members who were supposed to live in them. Three-bedroom apartments were provided for families with numerous members (Fig. 11).

Each building has two entrances, one that connects one-bedroom and two-bedroom apartments per floor and a second entrance that connects two-bedroom apartments and three-bedroom apartments per floor. In addition to well-built apartments, functional and well-connected spaces within each apartment, the main quality of this part of the workers' settlement is the urban composition. All buildings are set at a sufficient distance and allow large green spaces, good sunshine and parking spaces. This part of the workers' settlement has undergone the least changes over time (Fig. 12).

The workers' settlement Humci has many facilities, such as shops and craft shops. As a particularly valuable object, with its architecture, stands the kindergarten "Sunce" (Sun), which was designed by architect Pavle Popović in 1975. For this object, architect Popovic received the republic's "Borba" award. This award was granted to the best architectural solutions individually in each of the six Yugoslav republics as Republic "Borba" award. The most important award was the Federal "Borba" award, which was granted to best architectural objects on

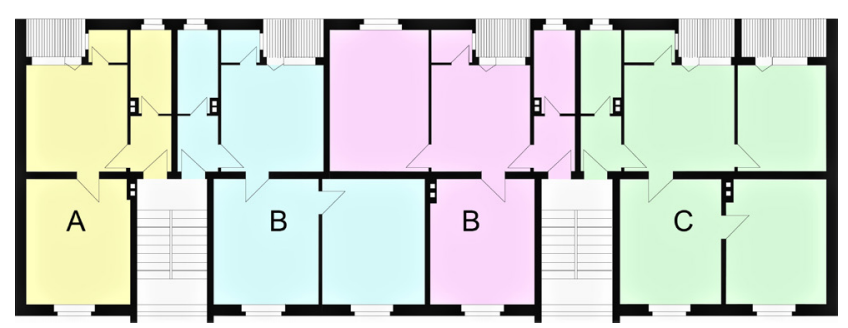

Fig. 11 Typical organisation of the apartments (Bojković, 2019)

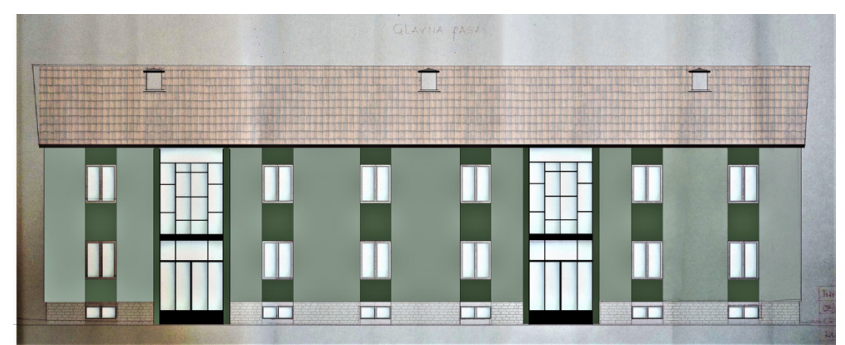

Fig. 12 The facade of a typical one-storey building in the workers' settlement Humci (Bojković, 2019)
Yugoslav territory. The kindergarten is the multiplication of the house modules in the almost archetypal form, just as the children represent the house. The construction of the building was done in concrete with the filling of a brick wall. The dominant elements of architecture are the roof surfaces with the drainage of water on four sides. Lanterns allow zenith lighting. The facility and spaces around it are completely suitable for the children's stay (Fig. 13).

Architect Butovski's plan provided a large park area around the settlement that would represent an additional quality of life. However, socio-economic conditions left a trace in Humci mainly in the form of unplanned construction and devastation of space.

\subsection{The workers' settlement "Budo Tomović"}

This workers' settlement is located near the ironworks and planned for several hundred workers and their families. The settlement is created in the form of parallel streets, which are joined by double-sided rectangular buildings in the form of clusters. Architect Vsevolod Butovski also built the settlement according to the plan (Fig. 14).

In the context of the typology of the building in the workers' settlement "Budo Tomović", a new type of housing organisation was presented (Fig. 15).

The buildings are designed for four families, each occupying one corner of the rectangular ground floor and first floor of the building. For the first time in the city, a duplex type of apartment has been designed in which the living area consisting of a kitchen, dining and living room and toilet is located on the ground floor and the night zone consisting of two bedrooms with a loggia located upstairs. The unusual characteristic of these buildings is reflected in the application of a flat roof, which was not the standard solution for Nikšić until then (Fig. 16).

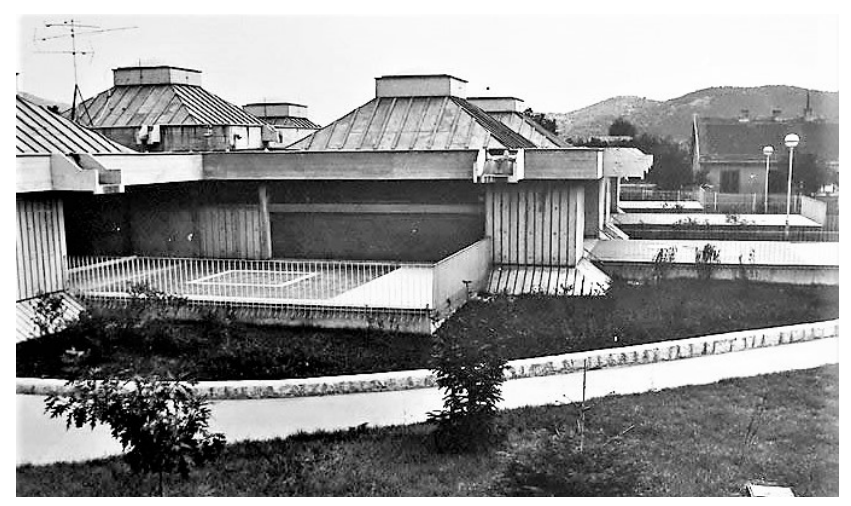

Fig. 13 Kindergarten "Sunce" (Sun), architect Pavle Popović, 1975 (Bojković, 2019) 


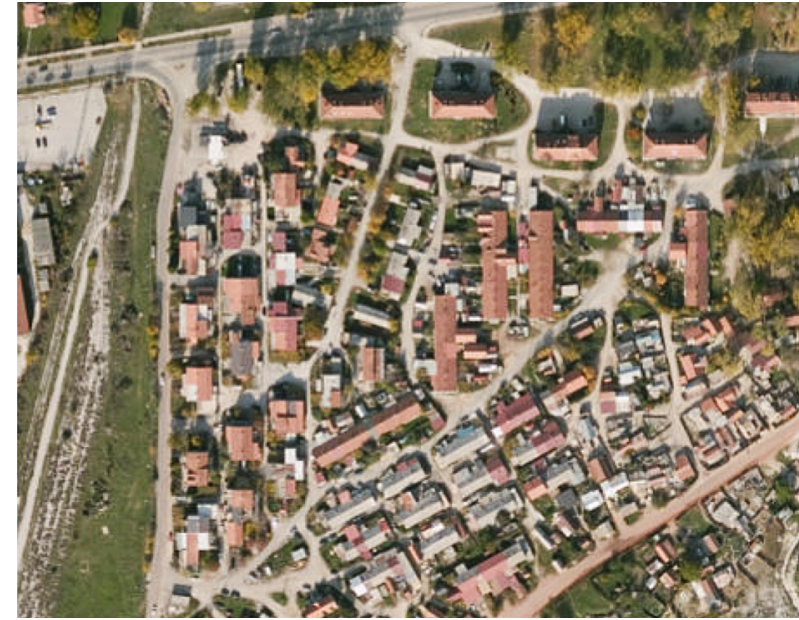

Fig. 14 Aerial view on the "Budo Tomović" settlement (Ministry of Sustainable Development and Tourism, Montenegro, 2020)

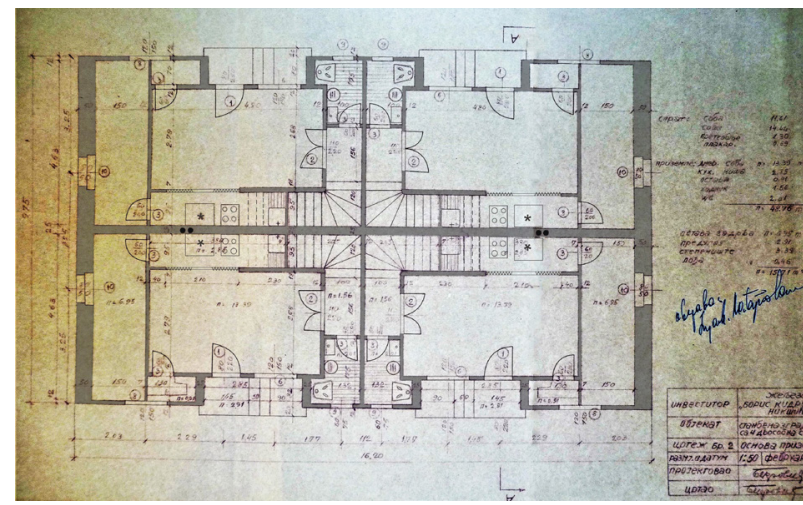

Fig. 15 Typical organization of the apartments (Bojković, 2019)

It seems that this settlement, especially in the later period, became a place of great devastation. Between workers' settlements Humci and Budo Tomović, the ironworks envisaged the construction of a large sports complex according to the plan by architect Kosta Popović.

\section{References}

Agence France Presse (2000) "List of International Sanctions Against Serbia" [online] Available at: https://www.globalpolicy.org/global-taxes/42528.html [Accessed: 15 May 2020]

Bjelica, O. (2009) "Ironworks company "Boris Kidrič”" [photography], Photo album, Nikšić: Ognjen Bjelica.

Bojković, V. (2006) "Workers' Settlement Humci" [photography], Photo album, Nikšić: Vladimir Bojković.

Bojković, V., Bajić, J. (2015) "Continuity of the development of Nikšić city through urban plans after World War II", In: Architecture and Urbanism after the Second World War, Protection as a Process or a Model, Zavod za zaštitu spomenika kulture grada Beograda, Belgrade, Serbia, pp. 38-49. [online] Available at: http://beogradskonasledje.rs/publikacije/istrazivanje/arhitektura-i-urbanizam-posle-drugog-svetskog-rata-zastita-kao-proces-ili-model [Accessed: 25 August 2019]

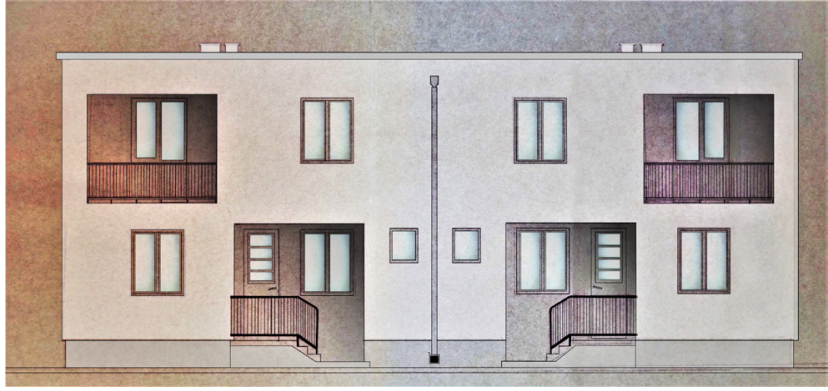

Fig. 16 The facades of a typical workers building (Bojković, 2019)

This complex had terrains for various types of sports, an athletic track and terrains for children. Unfortunately, this plan was not realised.

\section{Conclusion}

This paper aims to present the workers' settlements of Nikšić city for the first time. The main problem in preparing the paper was the lack of previous research, lack of archival material and adequate data.

Based on the analysis of the buildings of workers' settlements in the city of Nikšić, we can conclude that they had a significant influence on the architecture and urbanism of the city. First, they enabled the development of the urban structure logically, and in terms of the architecture of collective housing, new typologies were presented.

Buildings that had non-functional spaces underwent major alterations that ultimately resulted mainly in space devastation. A number of buildings that had functional spaces retained their original appearance.

It is expected that in the coming period, a more detailed study of this architectural and urban heritage will start as a valuable testimony to the development of the city in the twentieth century.

Bojković, V. (2018) "The Meander Building by Architect Bruno Milić; The Beginning of Modernism in the City of Nikšić", Prostor, 26(1), pp. $40-51$.

https://doi.org/10.31522/p.26.1(55).3

Bojković, V. (2019) "Architecture and Urbanism in the city of Nikšić after the Second World War", [monography], Special editon, 421, Belgrade: Zadužbina Andrejević.

Bojković, V. (2020) "Workers' Settlement Humci" [photography], Photo album, Nikšić: Vladimir Bojković.

Bulajić, Ž. (1972) "Moderne osnove Nikšića" (The Basics of Modern Nikšić), Grafički zavod Hrvatske, Zagreb, Croatia.

Ivanović, Z. (1979) "Nikšić, urbano-geografska studija" (Nikšić, the urban-geographical study), Beograd: SANU, Geografski Institut "Jovan Cvijic", Belgrade, Serbia. 
Kulić, V., Mrduljaš, M. (2012) "Modernism In-Between, The Mediatory Architectures of Socialist Yugoslavia", Jovis Verlag, Berlin, Germany.

Ministry of Sustainable Development and Tourism, Montenegro (2020) [online] Available at: https://mrt.gov.me/ministarstvo [Accessed: 18 March 2018]
Mićković, B. (2014) "Analysis of population trends in the municipality of Nikšić in the period 1948 - 2011.: Correlation with the processes of industrialisation and transition", Tehnika, 69(4), pp. 701-705. [online] Available at: http://scindeks.ceon.rs/article.aspx?artid=0040-21761404701M\&lang=en [Accessed: 15 March 2018] 